\title{
ANALISA PERBANDINGAN METODE SIMULATED ANNEALING DAN LARGE NEIGHBORHOOD SEARCH UNTUK MEMECAHKAN MASALAH LOKASI DAN RUTE KENDARAAN DUA ESELON
}

\section{COMPARISON ANALYSIS BETWEEN SIMULATED ANNEALING AND LARGE NEIGHBORHOOD SEARCH HEURISTICS FOR SOLVING TWO-ECHELON VEHICLE ROUTING PROBLEM}

\section{Winarno ${ }^{1, *}$, A. A. N. Perwira Redi ${ }^{2)}$}

1) Program Studi Teknik Industri, Fakultas Teknik, Universitas Singaperbangsa Karawang, Indonesia

2) Program Studi Teknik Logistik, Fakultas Teknologi Industri, Universitas Pertamina, Jakarta, Indonesia

\begin{tabular}{|c|c|}
\hline ARTICLE INFORMATION & A B S T R A C T \\
\hline $\begin{array}{l}\text { Article history: } \\
\text { Received: January 17, } 2020 \\
\text { Revised 1: February 10, } 2020 \\
\text { Accepted: April 09, } 2020\end{array}$ & $\begin{array}{l}\text { Two-echelon location routing problem (2E-LRP) is a problem that considers distribution } \\
\text { problem in a two-level / echelon transport system. The first echelon considers trips from } \\
\text { a main depot to a set of selected satellite. The second echelon considers routes to serve } \\
\text { customers from the selected satellite. This study proposes two metaheuristics algorithms } \\
\text { to solve 2E-LRP: Simulated Annealing (SA) and Large Neighborhood Search (LNS) } \\
\text { heuristics. The neighborhood / operator moves of both algorithms are modified }\end{array}$ \\
\hline $\begin{array}{l}\text { Keywords: } \\
\text { Two-Echelon Location Routing } \\
\text { Problem } \\
\text { Simulated Annealing } \\
\text { Large Neighborhood Search }\end{array}$ & $\begin{array}{l}\text { specifically to solve } 2 \mathrm{E} \text {-LRP. The proposed SA uses swap, insert, and reverse operators. } \\
\text { Meanwhile the proposed LNS uses four destructive operator (random route removal, } \\
\text { worst removal, route removal, related node removal, not related node removal) and two } \\
\text { constructive operator (greedy insertion and modived greedy insertion). Previously known } \\
\text { dataset is used to test the performance of the both algorithms. Numerical experiment } \\
\text { results show that SA performs better than LNS. The objective function value for SA and } \\
\text { LNS are } 176.125 \text { and } 181.478 \text {, respectively. Besides, the average computational time of } \\
\text { SA and LNS are } 119.02 \mathrm{~s} \text { and } 352.17 \mathrm{~s} \text {, respectively. }\end{array}$ \\
\hline
\end{tabular}

\section{A B S T R A K}

Kata kunci:

Masalah Lokasi dan Rute

Kendaraan Dua Eselon

Simulated Annealing

Large Neighborhood Search

\section{Corresponding Author}

Name : winarno

E-mail: winarno@staff.unsika.ac.id
Permasalahan penentuan lokasi fasilitas sekaligus rute kendaraan dengan mempertimbangkan sistem transportasi dua eselon juga dikenal dengan two-echelon location routing problem (2E-LRP) atau masalah lokasi dan rute kendaraan dua eselon (MLRKDE). Pada eselon pertama keputusan yang perlu diambil adalah penentuan lokasi fasilitas (diistilahkan satelit) dan rute kendaraan dari depo ke lokasi satelit terpilih. Pada eselon kedua dilakukan penentuan rute kendaraan dari satelit ke masing-masing pelanggan mempertimbangan jumlah permintaan dan kapasitas kendaraan. Dalam penelitian ini dikembangkan dua algoritma metaheuristik yaitu Simulated Annealing (SA) dan Large Neighborhood Search (LNS). Operator yang digunakan kedua algoritma tersebut didesain khusus untuk permasalahan MLRKDE. Algoritma SA menggunakan operator swap, insert, dan reverse. Algoritma LNS menggunakan operator perusakan (random route removal, worst removal, route removal, related node removal, dan not related node removal) dan perbaikan (greedy insertion dan modified greedy insertion). Benchmark data dari penelitian sebelumnya digunakan untuk menguji performa kedua algoritma tersebut. Hasil eksperimen menunjukkan bahwa performa algoritma SA lebih baik daripada LNS. Rata-rata nilai fungsi objektif dari SA dan LNS adalah 176.125 dan 181.478. Waktu rata-rata komputasi algoritma SA and LNS pada permasalahan ini adalah 119.02 dan 352.17 detik.

This is an open access article under the $\underline{\mathrm{CC}-\mathrm{BY}}$ license.

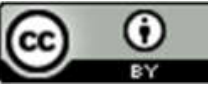




\section{PENDAHULUAN}

Masalah lokasi dan rute kendaraan dua eselon (MLRKDE) merupakan suatu model untuk memecahkan masalah sistem distribusi barang pada logistik perkotaan. Barang dikirim dari lokasi sumber ke lokasi tujuan dimana konsumen akhir berada. Untuk mencapai skala ekonomi, barang yang dikirim dari lokasi sumber menggunakan kendaraan dengan kapasitas besar. Namun penggunaan kendaraan besar di lokasi konsumen dilarang karena adanya keterbatasan lebar jalan dan kepadatan lalu lintas. Oleh karena itu, barangbarang tersebut dikirim menggunakan kendaraan yang lebih kecil. Fasilitas antara (satelit) diperlukan untuk memindahkan barang dari kendaraan besar ke kendaraan kecil.

Fungsi tujuan MLRKDE adalah untuk meminimasi total biaya distribusi barang yang terdiri dari biaya kendaraan di kedua eselon, biaya satelit, dan biaya rute kendaraan di kedua eselon. Kendaraan di eselon pertama akan menghubungkan sumber dengan satelit, sedangkan kendaraan di eselon kedua menghubungkan satelit dengan konsumen. Pemilihan lokasi satelit dan penentuan rute kendaraan yang tepat dapat mempercepat respon terhadap kebutuhan konsumen, meningkatkan kualitas pelayanan, dan meningkatkan kepuasan konsumen di dalam sistem logistik perkotaan. Ilustrasi MLRKDE disajikan dalam gambar 1. Dari gambar tersebut mengilustrasikan jaringan pengiriman barang dua eselon yang terdiri dari satu depo (segiempat), tiga satelit potensial (segilima), dan tujuh konsumen (lingkaran). Kendaraan berkapasitas besar berangkat dari depo menuju satelit-satelit terpilih (segilima garis penuh) dan kembali lagi ke depo, sehingga terbentuk rute kendaraan eselon 1 (garis panah tebal). Selanjutnya kendaraan berkapasitas lebih kecil mengangkut barang di satelit menuju konsumen-konsumen yang akan dilayani dan kembali lagi ke satelit, sehingga terbentuk rute kendaraan eselon 2 (garis panah tipis).

MLRKDE merupakan salah satu masalah optimasi kombinatorial yang NP-hard. Model tersebut sangat sulit diselesaikan dengan metode pemecahan eksak, oleh karena itu kebanyakan metode heuristik dipakai untuk memperoleh solusi mendekati optimal. Literatur menunjukkan bahwa para peneliti telah memecahkan MLRKDE menggunakan berbagai metode heuristik yang berbeda-beda. Berdasarkan pengetahuan penulis, simulated annealing (SA) merupakan salah satu metode heuristik dan telah banyak dipakai para peneliti untuk memecahkan masalah optimasi kombinatorial yang NP-hard [1-4].
Sedangkan hampir dua dekade banyak peneliti juga menggunakan metode heuristik large neighborhood search (LNS) untuk memecahkan masalah tersebut khususnya pada MLRKDE dan masalah rute kendaraan dua eselon (MRKDE).

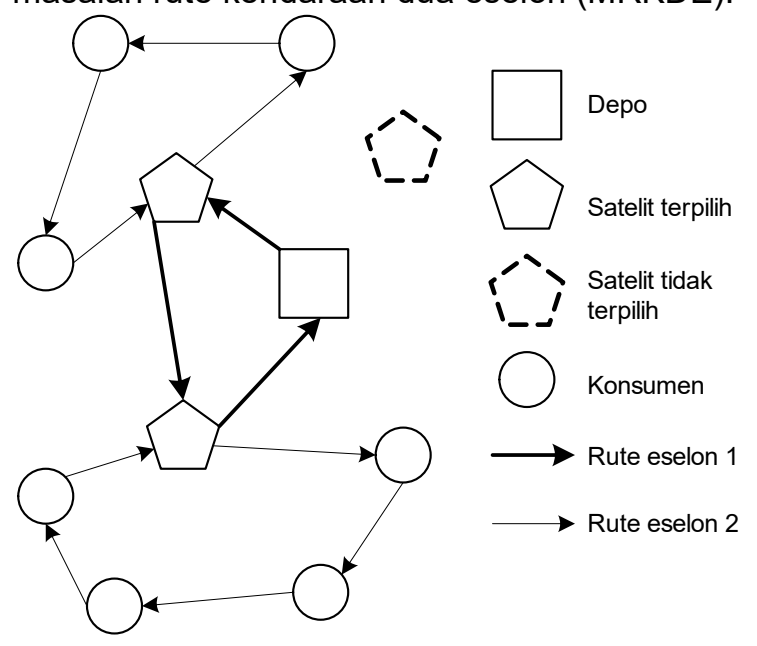

Gambar 1. Ilustrasi Masalah lokasi dan rute kendaraan dua eselon

Suatu masalah optimasi dapat dipecahkan dengan berbagai metode pemecahan yang berbeda. Beberapa peneliti membandingkan kinerja dua metode atau lebih untuk memecahkan masalah tersebut. Misalnya, [5] membandingkan kinerja heuristik descent, simulated annealing dan tabu search untuk menyelesaikan masalah rute kendaraan, sedangkan [6] mengajukan metode variable neighborhood search (VNS) dan metode hibrid VNS dan SA untuk memecahkan masalah lokasi dan rute kendaraan pada penanganan limbah padat. Dalam artikel ini, akan dilakukan analisis perbandingan antara metode SA dan LNS untuk memecahkan MLRKDE.

Cuda, et al. [7] mendefinisikan bahwa MRKDE adalah suatu model sistem distribusi barang yang melibatkan keputusan perencanaan tingkat taktis dan strategis, dan penentuan rute kendaraan yang ada di kedua eselon. Di dalam MRKDE, barang terletak di lokasi sumber yang biasa disebut depo akan dikirim ke lokasi tujuan melalui fasilitas antara yang biasa disebut satelit. Biaya pembukaan akan dibebankan ke setiap depo dan satelit. Depo dan satelit yang akan dibuka perlu dipilih dari sekumpulan lokasi depo atau satelit.

MRKDE pertama kali dikaji oleh Jacobsen and Madsen [8]. Peneliti tersebut mengkaji sistem distribusi surat kabar yang melibatkan titik-titik transfer untuk menghubungkan kantor percetakan dan para pengecer. Dewasa ini, setelah hampir empat dekade, beberapa metode heuristik telah diterapkan oleh para peneliti untuk menyelesaikan MRKDE. Metode heuristik seperti tabu search 
(TS)[9], variable neighborhood search (VNS) [10], greedy randomized adaptive search procedure (GRASP) dengan learning process dan path relinking [11], multi-start iterated local search (ILS) dengan path relinking [12], dan LNS [13] telah saling melengkapi satu sama lain untuk memecahkan MRKDE secara efisien. Hemmelmayr, et al. [14] juga menerapkan LNS untuk memecahkan MRKDE.

Sementara itu, ada metode heuristik (atau metaheuristik) yang sederhana, tetapi mampu menghasilkan solusi yang cukup bagus dengan waktu perhitungan yang relatif cepat. Di dalam literatur menunjukkan bahwa simulated annealing (SA) adalah metode metaheuristik yang sederhana tetapi mampu memecahkan masalah secara cepat. SA telah banyak diterapkan secara sukses di berbagai masalah optimasi kombinatorial yang cukup kompleks. Misalnya pada masalah penyusunan jadwal sekolah [1], tata letak fasilitas $[4,15]$, perancangan jaringan distribusi [2], turnamen perjalanan [16], penjadwalan mesin [3] dan rute kendaraan [17]. Lebih lanjut, di dalam Lin, et al. [18], SA digunakan untuk memecahkan masalah rute truk dan trailer (MRTT) secara efisien dengan hasil solusi yang bagus. Sebagai catatan bahwa MRTT ini berbeda dengan MLRKDE, namun demikian MRTT merupakan salah satu model masalah rute kendaraan dua eselon [7].

\section{METODE PENELITIAN}

Dalam artikel ini, penulis mengajukan metode heuristik dua tahap. Tahap awal merupakan pembentukan solusi awal untuk mendapatkan solusi secara cepat. Tahap berikutnya adalah memperbaiki solusi awal menggunakan metode heuristik. Selanjutnya, representasi solusi terdiri dari dua bagian, yaitu solusi eselon satu dan dua. Solusi eselon satu terdiri dari satu depo, sekumpulan satelit dan sejumlah angka nol imitasi (dummy zeros). Solusi eselon dua terdiri dari himpunan satelit, himpunan konsumen dan sejumlah dummy zeros.

Pada solusi eselon satu, setiap rute mulai dari depo. Selanjutnya satelit ditambahkan satu per satu tanpa melampaui kapasitas kendaraan eselon satu, dari kiri ke kanan ke dalam rute saat ini dan berakhir di depo. Pada solusi eselon dua, setiap rute berawal dari satelit. Konsumen ditambahkan satu per satu tanpa melanggar kapasitas kendaraan eselon kedua, dari kiri ke kanan ke dalam rute dari satelit saat ini, dan berakhir pada satelit. Dummy zeros di dalam kedua bagian solusi digunakan untuk menghentikan suatu rute dan memulai rute baru meskipun jumlah muatan kendaraan masih lebih kecil dari kapasitas kendaraan. Oleh karena itu, suatu rute dapat berakhir secara acak menggunakan dummy zero di dalam representasi solusi dan algoritma dapat mencari kesempatan lebih besar untuk mendapatkan solusi yang lebih baik.

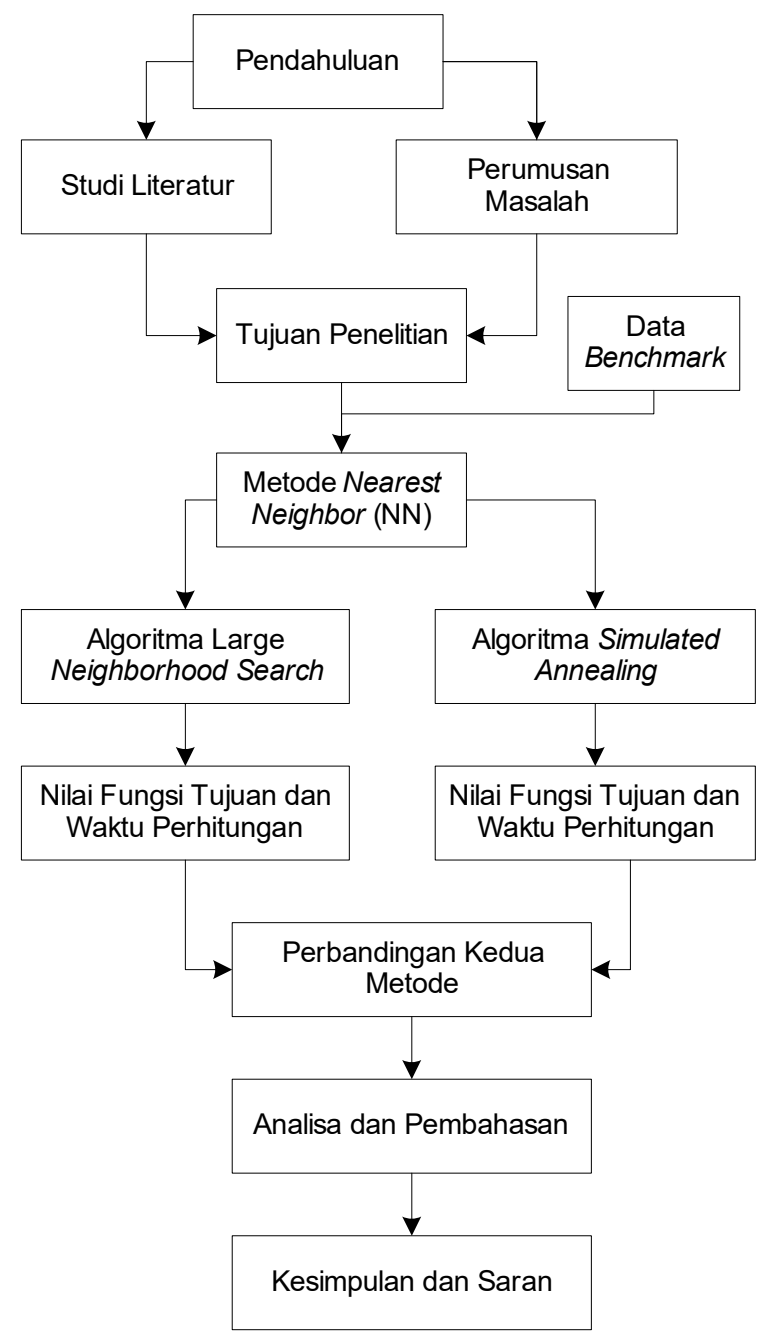

Gambar 2. Flow chart penelitian

Sebelum metode heuristik SA atau LNS diterapkan, inisial solusi dibentuk. Dalam artikel ini, pembentukan solusi awal di kedua eselon menggunakan metode nearest neighbor (NN). Di dalam eselon pertama, rute besar berawal dari depo, kemudian semua satelit ditambahkan satu per satu mengikuti aturan metode $\mathrm{NN}$ dengan tetap memperhatikan kapasitas kendaraannya dan berakhir di depo. Berikutnya, di eselon kedua, setiap konsumen dimasukkan ke dalam rute mengikuti aturan metode NN tanpa melanggar 
kapasitas kendaraannya. Jumlah muatan ruterute yang dilayani satelit di eselon kedua tidak diijinkan melewati kapasitas satelit. Kemudian, rute besar di eselon pertama diperbaharui rutenya tanpa melanggar kapasitas kendaraan eselon pertama.

Solusi hasil NN selanjutnya diperbaiki dengan metode SA dan LNS. Solusi dari kedua metode tersebut kemudian dibandingkan kinerjanya baik nilai fungsi tujuan maupun waktu perhitungannya. Dalam analisa dan pembahasan, selain perbandingan kinerja kedua metode tersebut, metode SA dan LNS juga dibandingkan dengan metode lain dari literatur. Tahap akhir dari penelitian ini berupa kesimpulan dan saran. Secara visual tahapan penelitian ini disajikan dalam Gambar 2.

\subsection{Simulated Annealing untuk MLRKDE}

Metode SA telah diperkenalkan oleh Metropolis, et al. [19]. Kirkpatrick, et al. [20] dan Eglese [21] mempopulerkan metode ini dengan melakukan tinjauan SA dalam masalah optimasi kombinatorial. SA telah diterapkan pada masalahmasalah optimasi kombinatorial termasuk masalah lokasi dan rute kendaraan (MLRK) Yu, et al. [22] dan masalah lokasi dan rute kendaraan terbuka (MLRKT) Yu and Lin [23]. Berikutnya, metode heuristik SA dengan representasi solusi khusus untuk MLRKDE juga akan diusulkan dalam penelitian ini.

Metode SA ini memerlukan lima parameter: $T_{0}$, $T_{\text {max }}, l_{i t e r}, N_{\text {non-improving, dan } \alpha} \alpha T_{0}$ merupakan temperatur awal; $T_{\max }$ adalah temperatur akhir; $I_{\text {iter }}$ menyatakan jumlah iterasi dalam pencarian solusi pada nilai temperatur yang sama; $N_{\text {non-improving }}$ menunjukkan frekuensi penurunan suhu yang dijinkan tanpa perbaikan solusi; dan $\alpha$ adalah koefisien laju penurunan temperatur.

Di dalam metode SA ini, temperatur awal $\left(T_{0}\right)$ ditetapkan sebagai temperatur saat ini $(T)$, nilai fungsi tujuan $X$ dinotasikan $f(X)$, solusi terbaik $\left(X_{\text {best }}\right)$ saat ini ditetapkan sebagai $X . F_{\text {best }}$ adalah nilai fungsi tujuan terbaik yang dicapai oleh SA saat ini dan diinisiasi sebagai $f(X)$. Setiap iterasi di temperatur tertentu melakukan mekanisme pencarian terdekat yang akan menghasilkan solusi baru $Y$ dari solusi $X$. Ditetapkan $\Delta$ sebagai selisih nilai fungsi tujuan antara solusi hasil pencarian terdekat dengan solusi saat ini, yaitu $\Delta=f(Y)-f(X)$. Jika $\Delta<0$, maka solusi baru lebih baik dari solusi saat ini dan $Y$ menggantikan $X$. Sebaliknya, jika $\Delta \geq 0$, solusi baru dapat diterima dengan probabilitas $\exp (-\Delta T)$. Proses penerimaan tersebut dilakukan dengan pembangkitan bilangan acak $r \sim U(0,1)$ dan penggantian $X$ dengan $Y$ jika $r<\exp (-\Delta T)$.

$\mathrm{SA}\left(T_{0}, T_{\text {max }}, I_{\text {iter }}, N_{\text {non-improving }}, \alpha\right)$

Tahap 1: Bangkitkan solusi awal X dengan metode NN

Tahap 2: $T=T_{0} ; I=0 ; N=0 ; F_{\text {best }}=f(X) ; X_{\text {best }}=X$

Tahap 3: $I=I+1$;

Tahap 4: (Bangkitkan solusi baru $Y$ berdasarkan solusi $X)$

Tahap 4.1: Bangkitkan bilangan acak $r(0,1)$

Tahap 4.2: Bangkitkan solusi $Y$ dari solusi $X$ sesuai $r$

Jika $r \leq 1 / 6$ : Lakukan perpindahan swap pada eselon pertama.

Jika $1 / 6<r \leq 2 / 6$ : Lakukan perpindahan swap pada eselon kedua.

Jika $2 / 6<r \leq 3 / 6$ : Lakukan perpindahan insert pada eselon pertama.

Jika $3 / 6<r \leq 4 / 6$ : Lakukan perpindahan insert pada eselon kedua.

Jika 4/6 $<r \leq 5 / 6$ : Lakukan perpindahan reverse pada eselon pertama.

Jika $r>5 / 6$ : Lakukan perpindahan reverse pada eselon kedua.

Tahap 5: Jika $f(Y)-f(X)<0$, maka $X=Y$, jika tidak maka bangkitkan bilangan acak $r(0,1)$. Jika $r<$ $\exp (-\Delta / T)$, maka $X=Y$.

Tahap 6: jika $f(X)<F_{\text {best }}$, maka $X_{\text {best }}=X, N=0$

Tahap 7: jika $I=I_{\text {iter }}$, maka $T=\alpha T ; I=0 ; N=N+1$;

Lakukan perpindahan swap pada $X_{\text {best }}$;

Lakukan perpindahan insert pada $X_{\text {best }}$;

Jika tidak kembali ke Tahap 3.

Tahap 8: jika $T \leq T_{\max }$ atau $N=N_{\text {non-improving }}$, maka algoritma SA stop. Jika tidak maka kembali ke Tahap 3.

Gambar 3. Pseudo code SA usulan

Temperatur saat ini turun menjadi $\alpha T, 0<\alpha<1$, setelah beroperasi sebanyak $l_{\text {iter }}$ iterasi pada temperatur saat ini. Algoritma akan berhenti jika terjadi dua kondisi: (i) temperatur saat ini $(T)$ di bawah atau sama dengan temperatur akhir ( $\left.T_{\max }\right)$, atau (ii) solusi terbaik sudah tidak dapat diperbaiki lagi sampai $N_{\text {non-improving. }}$ Solusi terbaik $\left(X_{\text {best }}\right)$ dan nilai fungsi tujuannya $\left(F_{\text {best }}\right)$ diperbaharui setiap memperoleh solusi terbaik yang baru ditemukan. Solusi MLRKDE terbaik diperoleh dari $X_{\text {best }}$ ketika algoritma berhenti. Metode heuristik SA yang diusulkan disajikan dalam pseudo code pada Gambar 3.

Perubahan solusi di dalam SA terjadi karena adanya mekanisme pencarian alternatif solusi 
terdekat. $\mathrm{Yu}$, et al. [22] dan $\mathrm{Yu}$ and Lin [23] menggunakan tiga operator perpindahan terdekat: swap, insert, dan reverse. Probabilitas pemilihan setiap operator perpindahan adalah 1/3. Di dalam penelitian ini, penulis melakukan pemilihan operator perpindahan dengan cara yang berbeda. Setiap operator perpindahan dilakukan secara terpisah di antara bagian solusi eselon pertama dengan eselon kedua. Oleh karena itu, di sini dilakukan enam perpindahan, yaitu: perpindahan swap eselon pertama, perpindahan swap eselon kedua, perpindahan insert eselon pertama, perpindahan insert eselon kedua, perpindahan reverse eselon pertama dan perpindahan reverse eselon kedua. Oleh karena itu, probabilitas dipilihnya setiap operator perpindahan adalah 1/6. Ilustrasi penerapan perpindahan dapat ditelusuri di dalam Yu and Lin [23]

\subsection{Large Neighborhood Search untuk MLRKDE}

Large neighborhood search (LNS) dalam artikel ini diadaptasi dari LNS yang disampaikan oleh Breunig, et al. [13]. Solusi awal secara iteratif dirusak dan diperbaiki agar diperoleh perbaikan solusi secara bertahap. Di dalam LNS ada dua jenis operator perubahan solusi, yaitu operator perusak dan operator perbaikan. Operator pertama akan mengambil sejumlah anggota solusi, sedangkan operator kedua akan menyisipkan kembali anggota yang diambil tersebut ke dalam solusi yang telah diambil anggotanya tersebut. LNS bekerja secara acak, dimana setiap operator dipilih berdasarkan bilangan acak $(0,1)$ yang telah dibangkitkan.

Gambar 4 menyajikan pseudo-code dari LNS usulan. Sesuai dengan [13], mekanisme perusakan dan perbaikan dilakukan pada setiap iterasi hanya pada solusi eselon kedua. Sedangkan solusi eselon pertama disusun menggunakan metode heuristik sederhana. Hal ini dilakukan karena ukuran solusi eselon pertama relatif kecil sehingga lebih mudah memperoleh solusi optimal atau mendekati optimal.

Setiap tahap perusakan menggunakan satu operator dari enam operator yang tersedia yang dipilih secara acak. Selanjutnya, mekanisme perbaikan dilakukan dengan merekonstruksi solusi. Dengan demikian mekanisme perusakanperbaikan dilakukan terus-menerus untuk memperbaiki solusi (Tahap 3-10). Jika solusi yang lebih baik diperoleh, maka solusi tersebut akan diterima sebagai solusi saat ini (Tahap 4-5). Selanjutnya jika solusi saat ini lebih baik dari solusi terbaik, maka solusi tersebut diterima sebagai solusi terbaik (Tahap 6-7). Sementara itu, jika perbaikan solusi tidak dapat diperoleh, algoritma akan merubah mekanisme pencarian alternatif solusi menggunakan mekanisme pencarian lokal (terdekat). Perubahan mekanisme perusakan-perbaikan ke mekanisme pencarian lokal dikontrol oleh parameter $N_{\text {MaxLNS }}$ (Tahap 10). $N_{\text {MaxLNS }}$ menyatakan jumlah maksimum iterasi tanpa perbaikan solusi yang dilakukan oleh mekanisme perusakan-perbaikan solusi. Ketika algoritma menjalankan mekanisme pencarian lokal, prosedurnya mirip dengan mekanisme perusakan-perbaikan. Secara konsep, Tahap 11-18 sama dengan Tahap 3-10. Perubahan mekanisme pencarian lokal ke mekanisme perusakan-perbaikan solusi dikontrol oleh parameter $N_{\text {MaxLS }}$ (Tahap 18). $N_{\text {MaxLS }}$ menyatakan jumlah maksimum iterasi tanpa perbaikan solusi yang dilakukan oleh mekanisme pencarian lokal.

Metode heuristik LNS menggunakan enam operator perusakan dan dua operator perbaikan. Keenam operator perusakan tersebut yaitu random route removal, worst removal, related node removal, not related node removal, smallest route removal, dan satellite removal. Sedangkan dua operator perbaikan terdiri dari greedy insertion dan modified greedy insertion.

Penjelasan keenam operator perusakan sebagai berikut. Pertama, random route removal akan memilih rute secara acak, kemudian semua konsumen dalam rute tersebut diambil (dirusak) dan dimasukkan ke penyimpanan konsumen. Kedua, worst removal didasarkan pada kemiripan operator seperti yang digunakan oleh [24] and [14]. Operator ini mengambil sejumlah $n$ konsumen dengan tingkat biaya terburuk. Biaya terburuk ini didefinisikan sebagai selisih biaya antara biaya ketika konsumen masuk bagian rute yang dirusak dengan biaya ketika konsumen tersebut tidak masuk ke rute tersebut. Operator ini dikontrol oleh parameter $W_{\alpha}$. Ketiga, related node removal didasarkan pada kemiripan operator seperti yang digunakan oleh [14]. Satu konsumen dipilih sembarang $\left(n_{x}\right)$ dan sejumlah $\mathrm{n}-1$ konsumen yang lokasinya terdekat dengan $n_{x}$ diidentifikasi. Semua konsumen ini kemudian diambil dari rute yang akan dirusak dan dimasukkan ke dalam penyimpanan konsumen. Jumlah konsumen yang diambil (dihapus) dikontrol oleh parameter $R_{\alpha}$. Keempat, not related node removal mirip dengan related node removal, perbedaannya terletak pada penentuan jumlah konsumen yang akan dihapus. Dalam operator 
keempat ini, sejumlah $n-1$ konsumen yang diidentifikasi adalah konsumen yang lokasinya terjauh dari $n_{x}$. Jumlah konsumen yang akan dihapus dikontrol oleh parameter $N R_{\alpha}$. Operator ini diterapkan dengan tujuan untuk mendiversifikasi pencarian solusi. Kelima, smallest route removal membuang rute dengan jumlah konsumen paling kecil. Keenam, satellite removal, operator ini diusulkan oleh [14]. Operator ini memilih secara acak salah satu satelit yang dibuka dan menutupnya, semua konsumen yag dilayani satelit tersebut dimasukkan ke dalam penyimpanan konsumen. Operator ini juga bermanfaat untuk diversifikasi dalam pencarian alternatif solusi.

LNS ( $\left.W_{\alpha}, R_{\alpha}, N R_{\alpha}, N_{\max L N S}, N_{\text {Max LS }}\right)$

Tahap 1: Bangkitkan solusi awal $X$ yang terdiri dari eselon 1 dan 2 dengan metode $\mathrm{NN}$

Tahap 2: $\quad N_{L N S}=0 ; N_{L S}=0 ; N=0 ; F_{\text {best }}=f(X) ; X_{\text {best }}=X$

Tahap 3: $Y=$ perbaikan(perusakan $(X))$

Tahap 4: Jika $f(Y)<f(X)$

Tahap 5: $\quad X=Y$

Tahap 6: $\quad$ Jika $f(X)<F_{\text {best }}$

Tahap 7: $\quad X_{\text {best }}=X ; F_{\text {best }}=f(X)$

Tahap 8: $\quad N_{L N S}=0$

Tahap 9: Jika tidak, maka $N_{L N S}=N_{L N S}+1$

Tahap 10: Jika $N_{L N S}=N_{\max L N S}$, maka lanjut ke Tahap 11, jika tidak lanjut ke Tahap 3.

Tahap 11: $\mathrm{Y}=$ pencarian lokal $(\mathrm{X})$

Tahap 12: Jika $f(Y)<f(X)$

Tahap 13: $\quad X=Y$

Tahap 14: Jika $f(X)<F_{\text {best }}$

Tahap 15: $\quad X_{\text {best }}=X ; F_{\text {best }}=f(X)$

Tahap 16: $\quad N_{L S}=0$

Tahap 17: Jika tidak, maka $N_{L S}=N_{L S}+1$

Tahap 18: Jika $N_{L S}=N_{\max L S}$, maka lanjut ke Tahap 3, jika tidak lanjut ke Tahap 11

Tahap 19: Algoritma berhenti setelah mencapai kriteria pemberhentian.

Tahap 20: Solusi akhir $=X_{\text {best }}$

Gambar 4. Pseudo code LNS usulan

Penjelasan berikutnya adalah dua operator perbaikan. Pertama, greedy insertion yang diadopsi dari operator yang digunakan oleh [14]. Operator ini menyisipkan konsumen secara acak satu per satu ke dalam posisi representasi solusi yang meminimalkan biaya distribusi pada setiap satelit yang dibuka dan rutenya. Kedua, modified greedy insertion yang diusulkan untuk diversifikasi pencarian solusi. Letak perbedaan dengan operator pertama adalah pada urutan konsumen di tempat penyimpanan konsumen sebelum disisipkan ke solusi yang telah dirusak. Metode pertama, sebelum disisipkan urutan konsumen di tempat penyimpanan tanpa mengalami perubahan, sedangkan pada metode kedua, urutan konsumen dibalik (reverse) terlebih dahulu sebelum disisipkan.

\section{HASIL PENELITIAN}

\subsection{Data Numerik untuk Pengujian Metode}

Metode heuristik yang diusulkan diterapkan dalam Microsoft Visual C++ 2012 dan dijalankan pada komputer Intel Core i7 $6700 \mathrm{CPU}$ pada $3.40 \mathrm{GHz}$ dan 8 GB RAM Windows 10. Cetak layar salah satu bagian program tersebut disajikan dalam Gambar 5. Untuk memahami kinerja dari metode heuristik SA dan LNS, penulis menguji kedua metode tersebut pada himpunan data numerik MLRDE dari Nguyen. Himpunan data numerik ini tersedia di Prodhon [25]. Himpunan data numerik tersebut terdiri dari satu depo dan dua grup satelit. Grup pertama terdiri dari lima satelit yang berisi 25,50 , dan 100 konsumen. Grup kedua terdiri dari 10 satelit yang berisi 50,100 , dan 200 konsumen. Dengan demikian himpunan data numerik tersebut terdiri dari 6 grup dengan berbagai kombinasi jumlah satelit dan konsumen. Di dalam penelitian ini, penulis memilih 12 data numerik yang terdiri dari dua data dari setiap grup.

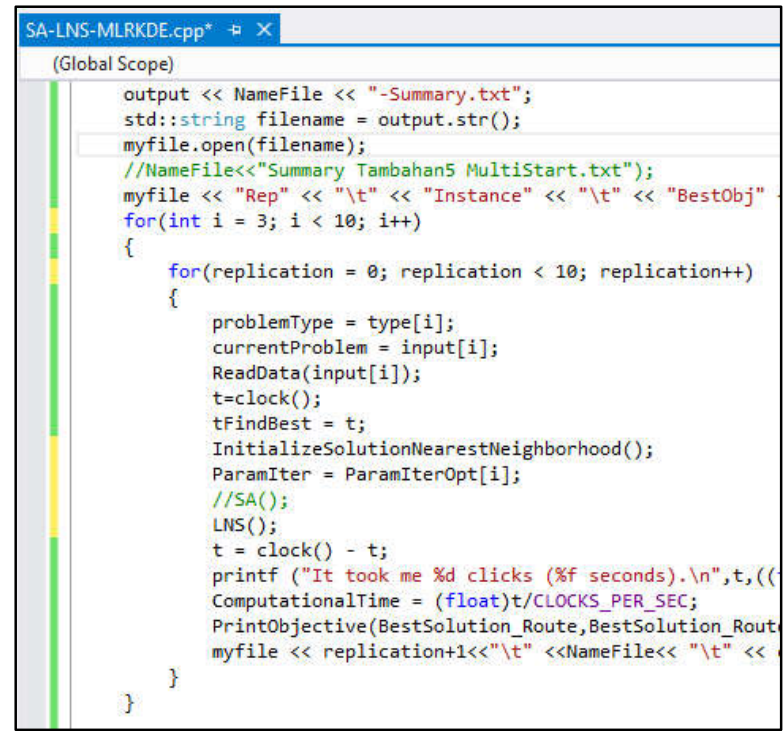

Gambar 5. Cetak layar salah satu bagian program dari metode yang diusulkan dalam $\mathrm{C}++$

\subsection{Nilai Parameter}

Pemilihan nilai parameter dapat mempengaruhi kualitas hasil perhitungan. Untuk percobaan awal, kombinasi nilai berbagai parameter SA usulan sebagai berikut:

$T_{0}=5,10,15$ 
$T_{\max }=0.01,0.001,0.0001$;

$l_{\text {iter }}=600 \mathrm{~L}, 800 \mathrm{~L}, 1000 \mathrm{~L}$, dimana $L$ adalah panjang (jumlah anggota) di dalam representasi solusi;

$N_{\text {non-improving }}=200,400,600$;

$\alpha=0.9,0.99,0.999$.

Setiap kombinasi nilai parameter dijalankan 20 kali. Hasil percobaan awal untuk menentukan nilai-nilai parameter dalam SA disajikan berbentuk grafik dalam Lampiran A. Penggunaan $T_{0}=10$, $T_{\max }=0.0001, l_{\text {iter }}=1000 \mathrm{~L}, N_{\text {non-improving }}=200$, dan $\alpha=0.9$ nampak menghasilkan hasil terbaik di antara semua kombinasi yang mungkin. Selanjutnya, nilai-nilai parameter tersebut digunakan dalam perhitungan berikutnya.

Sedangkan, percobaan awal untuk LNS usulan menggunakan kombinasi nilai parameter sebagai berikut:

$$
\begin{aligned}
& W_{\alpha}=8,10,12 ; \\
& R_{\alpha}=10,11,12 ; \\
& N R_{\alpha}=6,8,10 ; \\
& N_{\text {MaxLNS }}=5,10,15 ; \\
& N_{\text {MaxLS }}=50,75,100 .
\end{aligned}
$$

Setiap kombinasi nilai parameter dijalankan 20 kali. Hasil percobaan awal untuk menentukan nilai-nilai parameter dalam LNS disajikan berbentuk grafik dalam Lampiran $\mathrm{B}$. Penggunaan $W_{\alpha}=10, R_{\alpha}=10, N R_{\alpha}=6, N_{\text {MaxLNS }}=5$, dan $N_{\text {MaxLS }}$ = 75 nampak menghasilkan hasil terbaik di antara semua kombinasi yang mungkin. Selanjutnya, nilai-nilai parameter tersebut digunakan dalam perhitungan berikutnya.

\subsection{Hasil Percobaan}

Tabel 1 dan $2 \underline{2}$ menunjukkan kinerja kedua metode heuristik. Tabel 1 menyajikan nilai fungsi tujuan antara SA dan LNS. Setiap sampel dijalankan 10 kali. Kode sampel dikaitkan dengan jumlah satelit dan konsumen, sebaran lokasi konsumen dan kapasitas kendaraan di kedua eselon. Misalnya, sampel 25-5N menunjukkan bahwa sampel tersebut terdiri dari 25 konsumen dan 5 potensial satelit. Kode $\mathrm{N}$ menunjukkan lokasi konsumen menyebar mengikuti distribusi normal. Sedangkan kode b pada sampel $25-5 \mathrm{Nb}$ dan sampel-sampel lainnya menunjukkan bahwa kapasitas kendaraan yang dipakai di kedua eselon lebih besar dari kapasitas kendaraan dari sampel-sampel tanpa kode b. Kolom "Min(f)" menunjukkan nilai fungsi tujuan terkecil dari 10 kali pengulangan dan kolom "Rerata(f)" menunjukkan rata-rata nilai fungsi tujuan dari 10 kali pengulangan. Selanjutnya Tabel 2 menunjukkan waktu perhitungan dari kedua metode. Kolom "Min(t)" menunjukkan waktu yang diperlukan algoritma untuk menyelesaikan perhitungan. Waktu ini merupakan waktu tercepat dari 10 pengulangan. Sedangkan kolom "Rerata(t) menunjukkan rata-rata waktu perhitungan algoritma dari 10 kali pengulangan.

Tabel 1. Hasil nilai fungsi tujuan dari SA dan LNS

\begin{tabular}{lrrrr}
\hline Sampel & \multicolumn{1}{l}{ SA } & \multicolumn{2}{l}{ LNS } \\
& \multicolumn{1}{l}{ Min(f) } & Rerata(f) & \multicolumn{1}{l}{ Min(f) } & Rerata(f) \\
\hline $25-5 \mathrm{~N}$ & 80.370 & 81.954 & 80.370 & 83.473 \\
$25-5 \mathrm{Nb}$ & 64.562 & 66.115 & 64.562 & 65.786 \\
$50-5 \mathrm{~N}$ & 142.484 & 145.995 & 145.071 & 149.052 \\
$50-5 \mathrm{Nb}$ & 117.067 & 119.260 & 114.413 & 119.750 \\
$50-10 \mathrm{~N}$ & 120.572 & 123.021 & 119.476 & 123.502 \\
$50-10 \mathrm{Nb}$ & 90.057 & 95.826 & 94.869 & 100.981 \\
$100-5 \mathrm{~N}$ & 206.121 & 213.013 & 212.740 & 217.127 \\
$100-5 \mathrm{Nb}$ & 161.899 & 171.521 & 165.079 & 167.538 \\
$100-10 \mathrm{~N}$ & 226.232 & 231.235 & 239.357 & 249.625 \\
$100-10 \mathrm{Nb}$ & 171.304 & 181.511 & 184.451 & 189.471 \\
$200-10 \mathrm{~N}$ & 376.156 & 388.005 & 387.954 & 403.579 \\
$200-10 \mathrm{Nb}$ & 283.910 & 296.044 & 300.452 & 307.858 \\
Rerata & 170.061 & 176.125 & 175.733 & 181.478 \\
\hline
\end{tabular}

Berdasarkan Tabel 1, menunjukkan bahwa pada sampel kecil sampai 50 konsumen dan 10 satelit, kedua metode belum menunjukkan perbedaan kinerja secara signifikan. SA lebih bagus dari LNS pada sampel $50-5 \mathrm{~N}$ dan $50-10 \mathrm{Nb}$, sedangkan LNS lebih bagus dari SA pada sampel $50-5 \mathrm{Nb}$ dan 50-10N. Hal ini dapat diinterpretasikan bahwa penggunaan bilangan acak dalam pemilihan operator untuk menjalankan iterasi berikutnya belum signifikan perbedaannya di kedua metode ini untuk ukuran sampel relatif kecil. Sedangkan untuk ukuran sampel yang lebih besar solusi yang dihasilkan metode SA lebih baik daripada solusi LNS. Hal ini dimungkinkan karena pada metode SA adanya strategi untuk menghindari terjebaknya solusi optimal lokal dengan menerima solusi buruk dari solusi sebelumnya pada tingkat probabilitas tertentu, sedangkan pada metode LNS kriteria penerimaan solusi baru hanya didasarkan dari solusi yang lebih baik dari solusi sebelumnya. 
Tabel 2. Hasil waktu perhitungan dari SA dan LNS (dalam detik)

\begin{tabular}{lrrrr}
\hline Sampel & \multicolumn{1}{l}{ SA } & \multicolumn{2}{l}{ LNS } \\
& \multicolumn{1}{c}{ Min(t) } & Rerata(t) & \multicolumn{1}{c}{ Min(t) } & Rerata(t) \\
\hline $25-5 \mathrm{~N}$ & 0,05 & 6,93 & 0,17 & 44,03 \\
$25-5 \mathrm{Nb}$ & 0,04 & 6,66 & 0,13 & 44,39 \\
$50-5 \mathrm{~N}$ & 0,17 & 17,95 & 11,42 & 81,41 \\
$50-5 \mathrm{Nb}$ & 2,41 & 19,36 & 72,54 & 85,45 \\
$50-10 \mathrm{~N}$ & 15,13 & 25,50 & 53,04 & 76,20 \\
$50-10 \mathrm{Nb}$ & 4,22 & 14,44 & 17,92 & 76,96 \\
$100-5 \mathrm{~N}$ & 1,03 & 51,48 & 262,78 & 333,08 \\
$100-5 \mathrm{Nb}$ & 1,08 & 50,19 & 59,15 & 332,78 \\
$100-10 \mathrm{~N}$ & 33,11 & 89,12 & 195,11 & 326,28 \\
$100-10 \mathrm{Nb}$ & 7,98 & 62,72 & 235,44 & 248,12 \\
$200-10 \mathrm{~N}$ & 338,37 & 608,85 & $1.273,5$ & $1.315,43$ \\
$200-10 \mathrm{Nb}$ & 219,79 & 475,05 & 886,06 & $1.261,88$ \\
Rerata & 51,95 & 119,02 & 255,61 & 352,17 \\
\hline
\end{tabular}

Selanjutnya, rerata fungsi tujuan di Tabel 1 menunjukkan bahwa 10 dari 12 sampel yang diselesaikan dengan metode $\mathrm{SA}$ lebih bagus daripada LNS. Namun demikian yang perlu diperhatikan pada sampel $100-5 \mathrm{Nb}$, meskipun nilai fungsi tujuan terkecil dari 10 kali pengulangan pembangkitan solusi, tetapi rerata fungsi tujuan SA lebih tinggi daripada LNS. Hal tersebut dapat diintepretasikan bahwa pada sampel tersebut metode LNS lebih stabil dalam menghasilkan solusi.

Selanjutnya berdasarkan Tabel 2, secara keseluruhan metode $\mathrm{SA}$ juga lebih unggul dari metode LNS dari sisi waktu perhitungan. Konsep metode SA yang mengandalkan mekanisme pencarian alternatif solusi terdekat (lokal) membutuhkan waktu perhitungan yang lebih kecil dibandingkan dengan metode LNS. Konsep perusakan dan perbaikan solusi membutuhkan usaha yang lebih lama untuk menghasilkan solusi baru. Hal tersebutlah yang menyebabkan metode LNS memerlukan waktu perhitungan yang lebih lama. Namun demikian, kedua metode mempunyai kecenderungan yang sama dalam hal waktu perhitungan, yaitu semakin besar ukuran sampel maka akan semakin lama waktu perhitungan. Hal ini disebabkan ukuran iterasi dikaitkan dengan jumlah satelit dan konsumen, semakin besar jumlah entitas tersebut maka akan membutuhkan waktu yang lebih lama dalam menyelesaikan satu iterasi.

Metode SA dan LNS yang telah dikembangkan dalam artikel ini juga dibandingkan dengan metode greedy randomized adaptive search dengan learning process dan path relinking (GRASP-LP-PR) oleh [11] dan hibrid SA oleh [26] untuk menyelesaikan MLRKDE, yang masingmasing disajikan dalam Tabel 3 dan 4. Dalam Tabel 3, kolom SAs dan LNSs masing-masing merupakan persentase selisih antara nilai fungsi tujuan metode SA dan LNS dari Tabel 1 dengan nilai fungsi tujuan dari metode GRASP-LP-PR. Jika persentasenya positif, maka metode tersebut lebih baik dengan metode SA atau LNS, dan sebaliknya. Sebagai contoh nilai $3,8 \%$ dalam Tabel 3 kolom SAs dan sampel $50-5 \mathrm{Nb}$ menunjukkan bahwa pada sampel tersebut metode GRASP-LP-PR lebih bagus dari metode SA. Nilai tersebut diperoleh dari perhitungan $(117,067-112,764) / 112,764 \times 100 \%$. Berdasarkan Tabel 3 tersebut, hasil perhitungan metode SALNS sama dengan GRASP-LP-PR pada sampel $25-5 \mathrm{~N}$ dan $25-5 \mathrm{Nb}$, sedangkan pada sampel 50$5 \mathrm{~N}$, metode $\mathrm{SA}$ unggul $0,6 \%$. Sedangkan dalam Tabel 4, penjelasan kolom $\mathrm{SA}_{\mathrm{s}}$ dan LNSs mirip seperti yang telah dijelaskan dalam Tabel 3. Dari tabel tersebut menunjukkan bahwa hasil perhitungan SA-LNS sama dengan hibrid SA pada sampel $25-5 \mathrm{~N}$ dan $25-5 \mathrm{Nb}$. Sementara pada sampel $100-5 \mathrm{Nb}$, SA lebih unggul $0.6 \%$. Dari kedua tabel tersebut dapat disampaikan bahwa metode SA-LNS masih ada potensi untuk diperbaiki karena secara umum hasilnya masih di bawah GRASP-LP-PR dan hibrid SA terutama untuk sampel ukuran besar.

Tabel 3. Perbandingan hasil perhitungan SA-LNS dengan GRASP-PR

\begin{tabular}{lrrrr}
\hline Sampel & \multicolumn{1}{c}{ Min(f) } & Min(t) & \multicolumn{1}{l}{ SAs } & LNSs \\
\hline $25-5 \mathrm{~N}$ & 80,370 & 2.2 & $\mathbf{0 . 0} \%$ & $\mathbf{0 . 0 \%}$ \\
$25-5 \mathrm{Nb}$ & 64,562 & 1.8 & $\mathbf{0 . 0 \%}$ & $\mathbf{0 . 0 \%}$ \\
$50-5 \mathrm{~N}$ & 143,328 & 3.9 & $\mathbf{- 0 . 6 \%}$ & $1.2 \%$ \\
$50-5 \mathrm{Nb}$ & 112,764 & 3.6 & $3.8 \%$ & $1.5 \%$ \\
$50-10 \mathrm{~N}$ & 116,132 & 7.1 & $3.8 \%$ & $2.9 \%$ \\
$50-10 \mathrm{Nb}$ & 87,315 & 10 & $3.1 \%$ & $8.7 \%$ \\
$100-5 \mathrm{~N}$ & 196,999 & 8 & $4.6 \%$ & $8.0 \%$ \\
$100-5 \mathrm{Nb}$ & 159,714 & 8.5 & $1.4 \%$ & $3.4 \%$ \\
$100-10 \mathrm{~N}$ & 215,792 & 32.4 & $4.8 \%$ & $10.9 \%$ \\
$100-10 \mathrm{Nb}$ & 160,322 & 29.5 & $6.8 \%$ & $15.1 \%$ \\
$200-10 \mathrm{~N}$ & 357,286 & 35.9 & $5.3 \%$ & $8.6 \%$ \\
$200-10 \mathrm{Nb}$ & 264,241 & 77.6 & $7.4 \%$ & $13.7 \%$ \\
\hline Rerata & 163,235 & 18.4 & $3.4 \%$ & $6.2 \%$ \\
\hline
\end{tabular}


Tabel 4. Perbandingan hasil perhitungan SA-LNS dengan hibrid SA

\begin{tabular}{|c|c|c|c|c|}
\hline Sampel & $\operatorname{Min}(f)$ & $\operatorname{Min}(t)$ & SAs & LNSs \\
\hline $25-5 N$ & 80,370 & 2 & $0.0 \%$ & $0.0 \%$ \\
\hline $25-5 \mathrm{Nb}$ & 64,562 & 2 & $0.0 \%$ & $0.0 \%$ \\
\hline $50-5 N$ & 138,444 & 43 & $2.9 \%$ & $4.8 \%$ \\
\hline $50-5 \mathrm{Nb}$ & 111,840 & 31 & $4.7 \%$ & $2.3 \%$ \\
\hline $50-10 \mathrm{~N}$ & 116,132 & 42 & $3.8 \%$ & $2.9 \%$ \\
\hline $50-10 \mathrm{Nb}$ & 89,744 & 32 & $0.3 \%$ & $5.7 \%$ \\
\hline $100-5 \mathrm{~N}$ & 198,444 & 81 & $3.9 \%$ & $7.2 \%$ \\
\hline $100-5 \mathrm{Nb}$ & 162,813 & 60 & $-0.6 \%$ & $1.4 \%$ \\
\hline $100-10 N$ & 217,056 & 79 & $4.2 \%$ & $10.3 \%$ \\
\hline $\begin{array}{l}100- \\
10 \mathrm{Nb}\end{array}$ & 158,269 & 58 & $8.2 \%$ & $16.5 \%$ \\
\hline $200-10 \mathrm{~N}$ & 356,391 & 483 & $5.5 \%$ & $8.9 \%$ \\
\hline $\begin{array}{l}200- \\
10 \mathrm{Nb}\end{array}$ & 269,577 & 430 & $5.3 \%$ & $11.5 \%$ \\
\hline Rerata & 163,637 & 111.9 & $3.2 \%$ & $5.9 \%$ \\
\hline
\end{tabular}

\section{KESIMPULAN}

Dari hasil percobaan yang telah dilakukan dapat ditarik kesimpulan bahwa metode heuristik SA lebih unggul dibandingkan LNS ditinjau baik dari kualitas solusi maupun waktu perhitungan. MLRKDE dapat diterapkan di berbagai perusahaan distribusi barang dari pusat produksi ke area konsumen melalui fasilitas antara seperti distribusi media cetak, benda pos dan barang kebutuhan pokok lainnya.

Untuk kelanjutan penelitian berikutnya dapat disarankan hal-hal sebagai berikut: Menambahkan karakteristik lain pada model MLRKDE yang lebih mendekati masalah nyata seperti adanya rentang waktu pelayanan konsumen, rentang waktu tertentu di jalan-jalan penghubung antar lokasi sebagai efek program ganjil genap kendaraan yang bisa lewat pada jam tertentu. Mengkaji lebih lanjut penerapan metode heuristik LNS pada ukuran masalah yang lebih besar seperti melayani konsumen yang jumlahnya 1000 lokasi ke atas.

\section{DAFTAR PUSTAKA}

[1] D. Abramson, "Constructing school timetables using simulated annealing: sequential and parallel algorithms," Management science, vol. 37, pp. 98-113, 1991.

https://doi.org/10.1287/mnsc.37.1.98
[2] V. Jayaraman and A. Ross, "A simulated annealing methodology to distribution network design and management," European Journal of Operational Research, vol. 144, pp. 629-645, 2003. https://doi.org/10.1016/S03772217(02)00153-4

[3] S.-W. Lin, S.-Y. Chou, and S.-C. Chen, "Meta-heuristic approaches for minimizing total earliness and tardiness penalties of single-machine scheduling with a common due date," Journal of Heuristics, vol. 13, pp. 151-165, 2007. https://doi.org/10.1007/s10732-006$\underline{9002-2}$

[4] A. R. McKendall, J. Shang, and S. Kuppusamy, "Simulated annealing heuristics for the dynamic facility layout problem," Computers \& operations research, vol. 33, pp. 2431-2444, 2006. https://doi.org/10.1016/j.cor.2005.02.021

[5] A. Van Breedam, "Comparing descent heuristics and metaheuristics for the vehicle routing problem," Computers \& Operations Research, vol. 28, pp. 289315, 2001. https://doi.org/10.1016/S03050548(99)00101-X

[6] H. Asefi, S. Lim, M. Maghrebi, and S. Shahparvari, "Mathematical modelling and heuristic approaches to the locationrouting problem of a cost-effective integrated solid waste management," Annals of Operations Research, vol. 273, pp. 75-110, 2019. https://doi.org/10.1007/s10479-018$\underline{2912-1}$

[7] R. Cuda, G. Guastaroba, and M. G. Speranza, "A survey on two-echelon routing problems," Computers \& Operations Research, vol. 55, pp. 185199, 2015. https://doi.org/10.1016/j.cor.2014.06.008

[8] S. K. Jacobsen and O. B. Madsen, "A comparative study of heuristics for a twolevel routing-location problem," European Journal of Operational Research, vol. 5, pp. 378-387, 1980. https://doi.org/10.1016/03772217(80)90124-1

[9] M. Boccia, T. G. Crainic, A. Sforza, and C. Sterle, "A metaheuristic for a two echelon 
location-routing problem," in International Symposium on Experimental Algorithms, 2010, $\quad$ pp. 288-301. https://doi.org/10.1007/978-3-64213193-6_25

[10] M. Schwengerer, S. Pirkwieser, and G. R. Raidl, "A Variable Neighborhood Search Approach for the Two-Echelon LocationRouting Problem," in EvoCOP, 2012, pp. 13-24. https://doi.org/10.1007/978-3642-29124-1_2

[11] V.-P. Nguyen, C. Prins, and C. Prodhon, "Solving the two-echelon location routing problem by a GRASP reinforced by a learning process and path relinking," European Journal of Operational Research, vol. 216, pp. 113-126, 2012 https://doi.org/10.1016/j.ejor.2011.07.030

[12] V.-P. Nguyen, C. Prins, and C. Prodhon, "A multi-start iterated local search with tabu list and path relinking for the twoechelon location-routing problem," Engineering Applications of Artificial Intelligence, vol. 25, pp. 56-71, 2012. https://doi.org/10.1016/j.engappai.2011.0 $\underline{9.012}$

[13] U. Breunig, V. Schmid, R. Hartl, and T. Vidal, "A large neighbourhood based heuristic for two-echelon routing problems," Computers \& Operations Research, vol. 76, pp. 208-225, 2016. https://doi.org/10.1016/j.cor.2016.06.014

[14] V. C. Hemmelmayr, J.-F. Cordeau, and T. G. Crainic, "An adaptive large neighborhood search heuristic for twoechelon vehicle routing problems arising in city logistics," Computers \& operations research, vol. 39, pp. 3215-3228, 2012. https://doi.org/10.1016/j.cor.2012.04.007

[15] L. Chwif, M. R. P. Barretto, and L. A. Moscato, "A solution to the facility layout problem using simulated annealing," Computers in industry, vol. 36, pp. 125132, 1998.

[16] A. Lim, B. Rodrigues, and X. Zhang, "A simulated annealing and hill-climbing algorithm for the traveling tournament problem," European Journal of Operational Research, vol. 174, pp. 14591478 , 2006. https://doi.org/10.1016/S01663615(97)00106-1
[17] A. Van Breedam, "Improvement heuristics for the vehicle routing problem based on simulated annealing," European Journal of Operational Research, vol. 86, pp. 480490, 1995. https://doi.org/10.1016/0377$\underline{2217(94) 00064-J}$

[18] S.-W. Lin, F. Y. Vincent, and S.-Y. Chou, "Solving the truck and trailer routing problem based on a simulated annealing heuristic," Computers \& Operations Research, vol. 36, pp. 1683-1692, 2009. https://doi.org/10.1016/i.cor.2008.04.005

[19] N. Metropolis, A. W. Rosenbluth, M. N. Rosenbluth, A. H. Teller, and E. Teller, "Equation of state calculations by fast computing machines," The journal of chemical physics, vol. 21, pp. 1087-1092, 1953. https://doi.org/10.1063/1.1699114

[20] S. Kirkpatrick, J. C. Gelatt, and M. P. Vecchi, "Optimization by simmulated annealing," science, vol. 220, pp. 671680 , 1983. https://doi.org/10.1126/science.220.4598. $\underline{671}$

[21] R. Eglese, "Simulated annealing: a tool for operational research," European journal of operational research, vol. 46, pp. 271281, 1990. https://doi.org/10.1016/03772217(90)90001-R

[22] V. Yu, F., S.-W. Lin, W. Lee, and C.-J. Ting, "A simulated annealing heuristic for the capacitated location routing problem," Computers \& Industrial Engineering, vol. 58, pp. 288-299, 2010. https://doi.org/10.1016/j.cie.2009.10.007

[23] V. F. Yu and S.-Y. Lin, "A simulated annealing heuristic for the open locationrouting problem," Computers \& Operations Research, vol. 62, pp. 184196, 2015. https://doi.org/10.1016/i.cor.2014.10.009

[24] S. Ropke and D. Pisinger, "An adaptive large neighborhood search heuristic for the pickup and delivery problem with time windows," Transportation science, vol. 40, pp. 455-472, 2006. https://doi.org/10.1287/trsc.1050.0135

[25] C. Prodhon. (2016, 11 January 2020). LRP-2E instances. Available: http://prodhonc.free.fr/Instances/instance s0 us.html 
[26] K. Pichka, A. H. Bajgiran, M. E. Petering, J. Jang, and $X$. Yue, "The two echelon open location routing problem: Mathematical model and hybrid heuristic," Computers \& Industrial Engineering, vol. 121, pp. 97-112, 2018. https://doi.org/10.1016/j.cie.2018.05.010

\section{Biografi Penulis}

\section{Winarno}

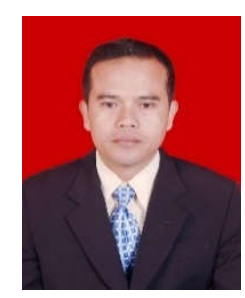

Winarno merupakan dosen tetap di Program studi Teknik Industri, Universitas Singaperbangsa Karawang. Memperoleh gelar S2 di jurusan Teknik dan Manajemen Industri - Institut Teknologi Bandung dan sedang menyelesaikan program S3 di

National Taiwan University of Science and Technology (NTUST). Mempunyai pengalaman sebagai Ketua Program Studi Teknik Industri, Universitas Singaperbangsa Karawang pada masa jabatan 2011-2015.

\section{A. A. N. Perwira Redi}

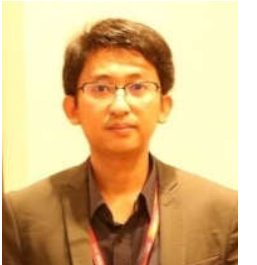

Dr. Redi adalah dosen tetap Jurusan Teknik Logistik Universitas Pertamina. Berpengalaman sebagai

Research Fellow di Monash University, Australia.

Memperoleh gelar S2 dan S3 di National Taiwan University of Science and Technology (NTUST).

\section{Lampiran A}

Hasil percobaan awal untuk menentukan nilai nilai parameter SA

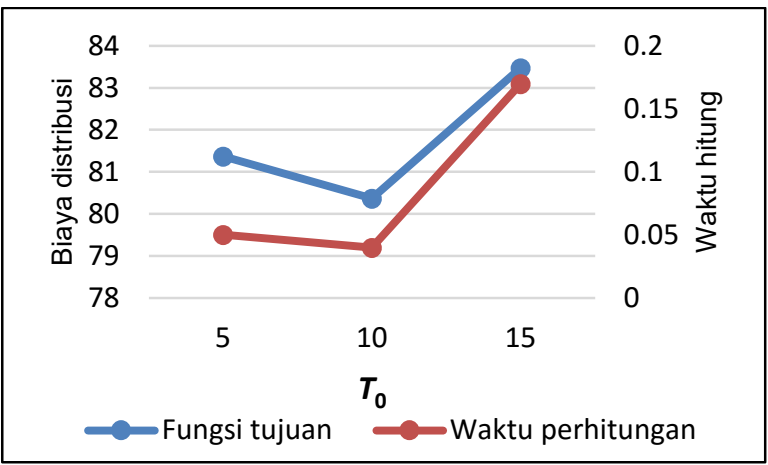

Gambar A1. Setting nilai parameter $T_{0}$

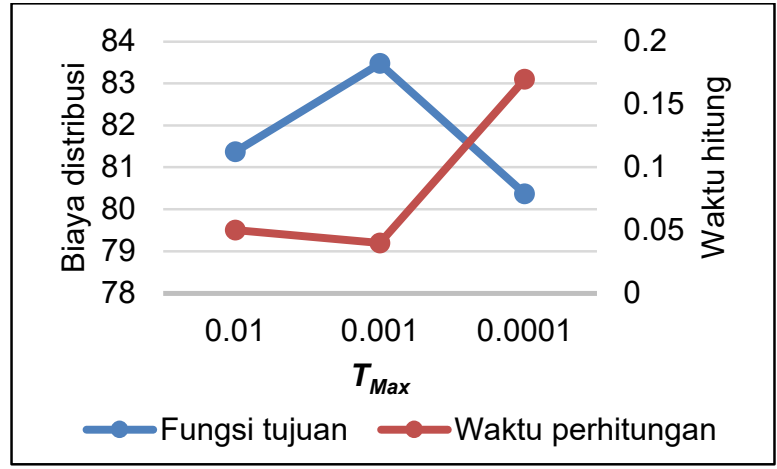

Gambar A2. Setting nilai parameter $T_{\mathrm{Max}}$

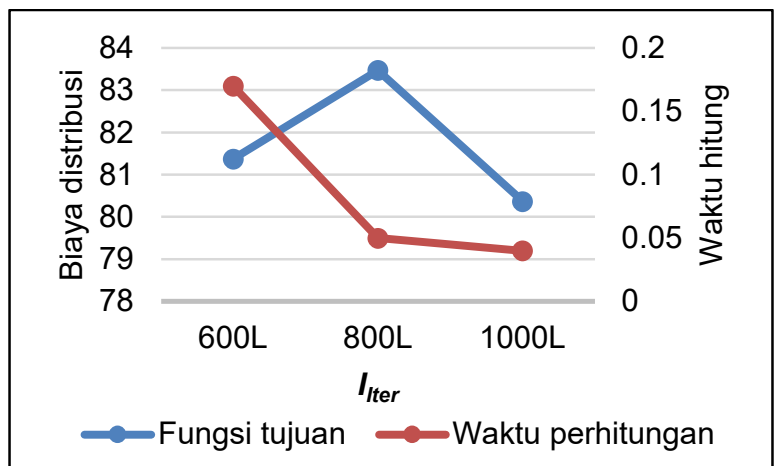

Gambar A3. Setting nilai parameter $I_{\text {Iter }}$

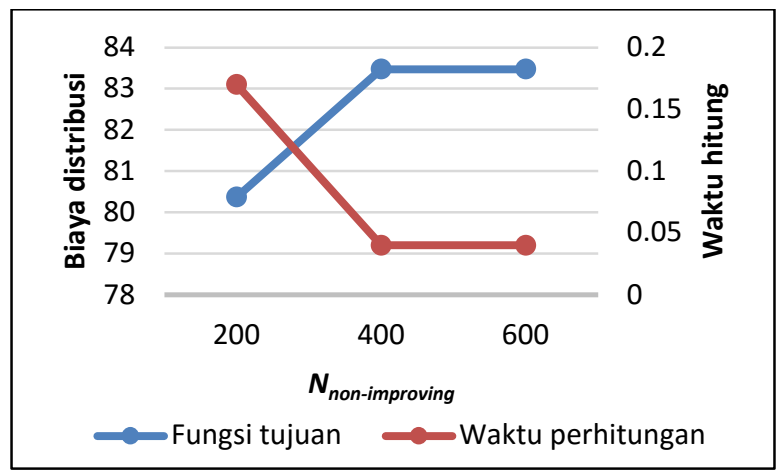

Gambar A4. Setting nilai parameter $N_{\text {Non-improving }}$

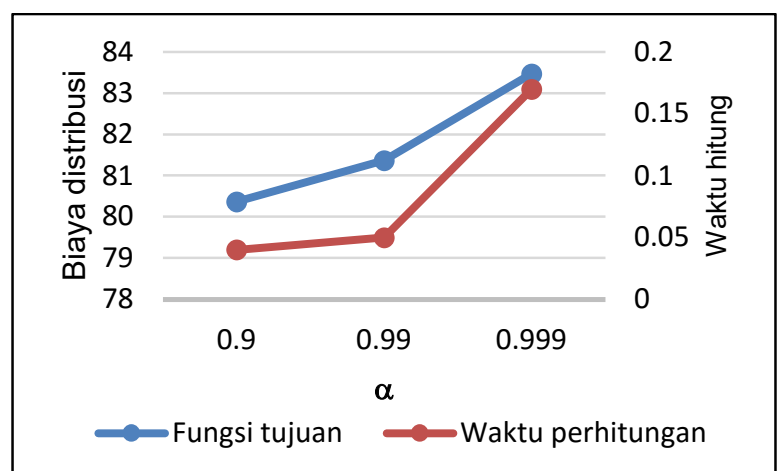


Gambar A5. Setting nilai parameter $\alpha$ Lampiran B

Hasil percobaan awal untuk menentukan nilai-nilai parameter LNS.

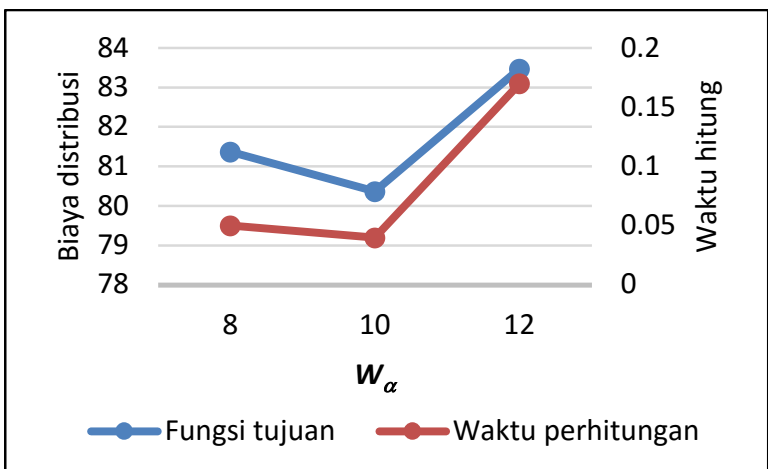

Gambar B1. Setting nilai parameter $W_{\alpha}$

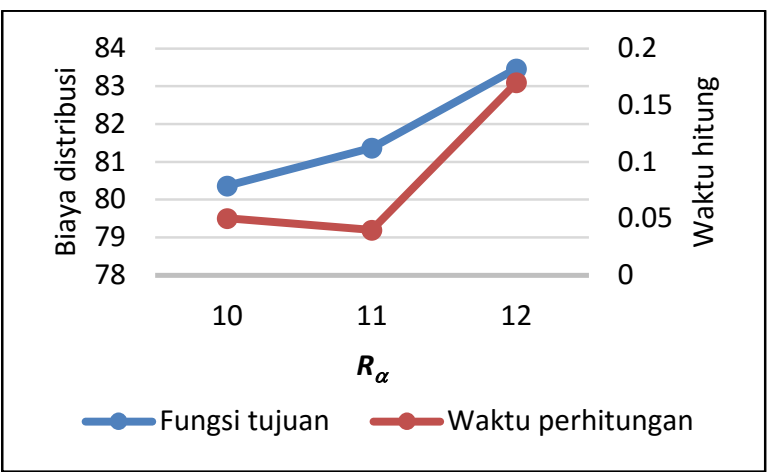

Gambar B2. Setting nilai parameter $R_{\alpha}$

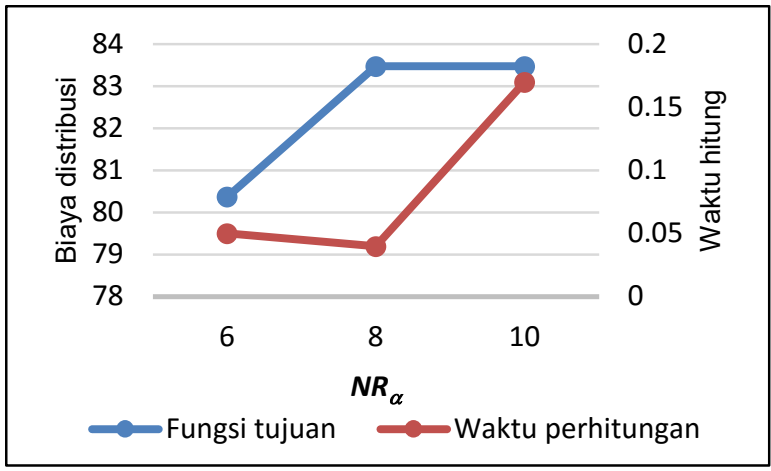

Gambar B3. Setting nilai parameter $N R \alpha$

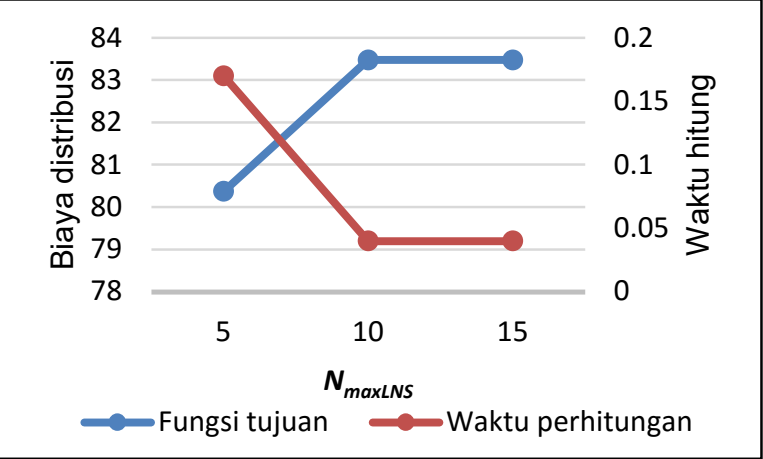

Gambar B4. Setting nilai parameter $N_{M a x L N S}$

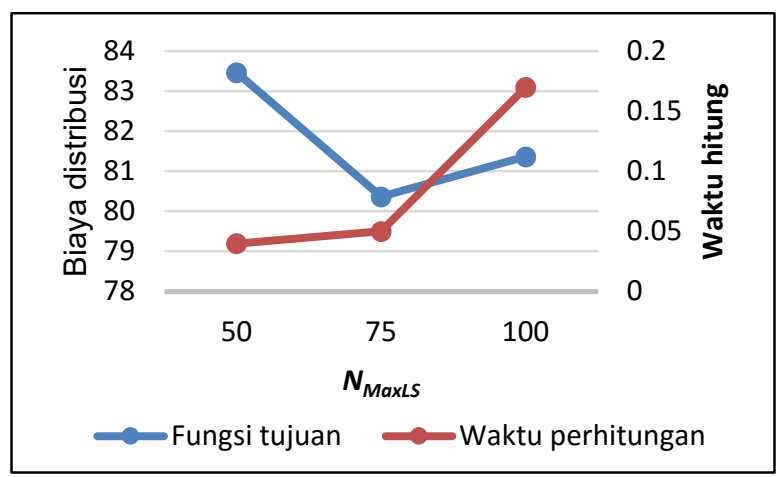

Gambar B4. Setting nilai parameter $N_{\text {MaxLS }}$ 